\title{
LYSINE, METHIONINE AND CYSTINE REQUIREMENTS OF SEMI-HEAVY LAYERS
}

\author{
M. PICARD \\ avec la collaboration technique de S. Bertrand et de J. Salvert \\ Service zootechnique, A. E. C., \\ 03600 Commentry
}

Two different strains of commercial semi-heavy layers received natural diets containing $2700 \mathrm{kcal}$ metabolisable energy per $\mathrm{kg}$.

The following levels of essential amino acids were obtained by adding DL-méthionine or/and L-lysine :

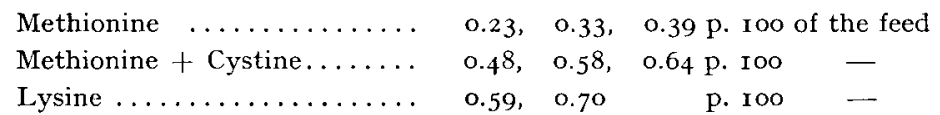

These experimental feeds were given ad libitum to the birds kept in individual cages during $4^{\circ}$ weeks' laying. Individual controls of production and feed consumption were carried out every four weeks. For each level of supplementation, there were 48 replicates for one strain and 60 for the other of a single hen.

The results were considered over the total laying period.

- A significant effect has been noted between the two lower levels of methionine $(5 \mathrm{p}$. 100 difference in feed conversion).

- The daily methionine requirement of layers has been estimated to be ranged between 360 and $390 \mathrm{mg}$.

- No difference has been recorded in the performances of birds receiving :

$0.5^{8}$ p. roo or 0.64 p. Ioo of total sulphur amino acids,

0.59 p. 100 or 0.70 p. Ioo of lysine.

This trial confirms our previous works. A semi-heavy layer is largely satisfied by a feed containing :

$2700 \mathrm{kcal}$ metabolisable energy $/ \mathrm{kg}$,

$0.3^{\circ}$ p. I 100 methionine,

0.54 p. Ioo total sulphur amino acids (T. S. A. A.),

0.59 p. roo lysine.

But it is quite necessary to control not only the T. S. A. A. content of commercial feeds but also their methionine content. 